\title{
Effect of Copperoxychloride on the Fermentation of Must and on Wine Quality
}

\author{
A. Tromp* and C.A. de Klerk \\ Viticultural and Oenological Research Institute (VORI), Private Bag X5026, 7600 Stellenbosch, Republic of South Africa. \\ ${ }^{*}$ Present address: Subdirectorate Liquor Control, Private Bag X5052, 7600 Stellenbosch, Republic of South Africa.
}

Submitted for publication: April 1988

Accepted for publication: May 1988

Keywords: Grapevines, Copper, Fermentation, Wine Quality

\begin{abstract}
A Chenin blanc and a Colombar vineyard was sprayed with copperoxychloride $(\mathrm{CuOCl})$ in different spraying programs. A laboratory trial was conducted where copper in different concentrations was added to grape must and fermented. Copper concentrations were determined in musts and wines, fermentation curves established and wine quality assessed. Results show that spraying a vineyard with $\mathrm{CuOCl}$ for 5 or 6 consecutive sprays up to 14 or 3 days before harvest respectively caused copper concentrations of $13-44 \mathrm{mg} / \mathrm{l}$ in the settled musts. Spraying a vineyard at $14+7+3$ days before harvest yielded a must with a copper concentration of $16 \mathrm{mg} / \mathrm{l}$. These musts as well as a must to which $10 \mathrm{mg} / \mathrm{l}$ of copper was added, underwent slower fermentation than their respective controls. Wine quality was seriously impaired. It is concluded that the closer to harvest the last copper spray is applied, the more problems will be encountered.
\end{abstract}

The use of copper containing fungicides leads to copper residues in musts which may cause lagging fermentation and affect wine quality detrimentally. Lemperle \& Lay (1984) found a copper concentration of $34 \mathrm{mg} / \mathrm{l}$ in grapes 14 days after the last treatment with copper lime. Although most of this copper will be lost during extraction and clarification of the juice, it can be expected that some copper will be found in the must. The copper concentration of a settled must obtained from grapes which had received five sprays of copperoxychloride with the last spray applied one week before harvest, was in fact found to be $3,91 \mathrm{mg} / l$ (Eschenbruch \& Kleynhans, 1974). Würdig (1969) similarly quotes copper concentrations of $15 \mathrm{mg} / \mathrm{l}$ or even higher in musts and states that if more than $0,5 \mathrm{mg} / \mathrm{l}$ of copper is found in wine, the initial copper concentration of the must was at least $10 \mathrm{mg} / l$. The amount of copper removed by the yeast is of great importance as residual copper in the wine can cause browning (Diaz, 1979) and turbidity (Würdig, 1969). In this respect Thoukis \& Amerine (1956) found that although yeast, used in their work, was able to assimilate up to $13 \mathrm{mg} / l$ at high copper concentrations, residues of as high as $2 \mathrm{mg} / \mathrm{l}$ were found in wine where the initial copper concentration in the must was only $5 \mathrm{mg} / l$.

Many authors report on the effect of copper on fermentation. Whilst Conner (1983) found yeasts "comparatively insensitive to copper", Würdig (1969) and Tromp (1980) indicated copper as a cause of stuck fermentations at concentrations of $15 \mathrm{mg} / l$ and even as low as $8 \mathrm{mg} / l$, respectively. Cuprosan, when used with other fungicides (Sapis-Domerq et al. 1978), or alone (Sapis-Domerq, 1980) also caused fermentation problems.

The quality of Concord grape juice was negatively affected by spraying the vineyard with copperoxychloride (Haeseler \& Petersen, 1974). Although Dieter (1979) found no difference between wines from copper treated and untreated grapes, it is common knowledge that copper residues in either musts or wine will lower wine quality because of either $\mathrm{H}_{2} \mathrm{~S}$ formation (Eschenbruch, 1971; Eschenbruch \& Kleynhans, 1974), oxidation (Thoukis \& Amerine, 1956; Würdig, 1969; Diaz, 1979) or the formation of turbidity.

Copperoxychloride is widely used in South African vineyards for the control of downy mildew (Plasmopara viticola) and to a lesser extent against dead arm (Phomopsis viticola) and anthracnose (Gloeosporium ampelophagum).

The purpose of this study was to quantify copper residues in musts from vines treated with copperoxychloride and to determine the effect of these residues on the rate of fermentation and on resultant wine quality.

\section{MATERIALS AND METHODS}

Two field trials and one laboratory experiment were conducted.

\section{Field Trials}

To assess the effect of $\mathrm{CuOCl}$ on the fermentation of must and subsequent wine quality, trials were conducted with the cultivars Chenin blanc and Colombar. The Chenin blanc vineyard is situated at Robertson (Region V) and three treatments, replicated four times, were applied (Table 1). The Colombar vineyard is situated at Stellenbosch (Region IV) and seven treatments, replicated four times, were applied (Table 2).

Treatments were applied by handspray in both instances. After picking, the grapes were destemmed and crushed with addition of $70 \mathrm{mg} / \mathrm{l}$ of $\mathrm{SO}_{2}$. The free run juice was collected, treated with $80 \mathrm{~g} / \mathrm{h} l$ of bentonite and allowed to settle overnight at $0^{\circ} \mathrm{C}$ whereafter the clear juice was racked from its lees. The Chenin blanc and Colombar musts were respectively fermented in $5 l$ and $20 l$ containers. All musts were inoculated with rehydrated dried yeast (Strain WE 500 from the VORI 
TABLE 1

Application dates and volumes for copperoxychloride treatments applied on a Chenin blanc vineyard at Robertson.

\begin{tabular}{|c|c|c|c|c|c|c|c|}
\hline \multirow{2}{*}{ TREATMENTS } & \multicolumn{6}{|c|}{ APPLICATION DATES AND VOLUMES ${ }^{a)}(1)$} & \multirow{2}{*}{ HARVEST DATE } \\
\hline & \multicolumn{6}{|c|}{ 1985.10.101985.11.21 1985.12 .121986 .01 .071986 .01 .301986 .02 .10} & \\
\hline 1. Control & - & - & - & - & - & - & 1986.02 .13 \\
\hline $\begin{array}{l}\text { 2. Application up to } 14 \text { days } \\
\text { before harvest }\end{array}$ & 500 & 750 & 1000 & 1000 & 1000 & - & 1986.02 .13 \\
\hline $\begin{array}{l}\text { 3. Application up to } 3 \text { days } \\
\text { before harvest }\end{array}$ & 500 & 750 & 1000 & 1000 & 1000 & 1000 & 1986.02 .13 \\
\hline
\end{tabular}

${ }^{\text {a) } V o l u m e s ~ o f ~} \mathrm{CuOCl}$ mixture applied per hectare at a rate of $550 \mathrm{~g} / 100 \mathrm{l}$ water.

TABLE 2

Application dates and volumes for copperoxychloride treatment applied on a Colombar vineyard in Stellenbosch.

\begin{tabular}{l|c|c|c|c}
\hline \multirow{2}{*}{$\begin{array}{c}\text { TREATMENTS } \\
\text { (DAYS BEFORE }\end{array}$} & \multicolumn{2}{|c|}{ APPLICATION DATES AND VOLUMES ${ }^{\text {a) }}$ (l) } & \multirow{2}{*}{ HARVEST DATE } \\
\cline { 2 - 4 } \multicolumn{1}{c|}{ HARVEST) } & 1986.02 .24 & 1986.03 .03 & 1986.03 .07 & \\
\hline Control & - & - & - & 1986.03 .10 \\
14 & 1000 & $1-$ & - & 1986.03 .10 \\
7 & - & $1-$ & 1000 & 1986.03 .10 \\
3 & 1000 & 1000 & 1000 & 1986.03 .10 \\
$14+7+3$ & 1000 & - & 1000 & 1986.03 .10 \\
$14+7$ & 1000 & & - & 1986.03 .10 \\
$14+3$ & &
\end{tabular}

${ }^{\text {a) }}$ Volumes of $\mathrm{CuOCl}$ applied per hectare at a rate of $500 \mathrm{~g} / 100 l$ water

collection) at $0,5 \mathrm{~g} / l$. Fermentation curves were obtained by plotting daily mass loss due to the evolution of $\mathrm{CO}_{2}$. Following fermentation the wines were racked, filtered, stabilised against tartrate sedimentation by storing at $0^{\circ} \mathrm{C}$ for 3 weeks and then bottled. The free sulphur dioxide concentration of the wines was kept at $30 \mathrm{mg} / \mathrm{l}$ throughout the process of vinification. The copper concentration of all settled musts was determined utilising standard VORI methods. The colour density of the Colombar wines was determined spectrophotometrically at $420 \mathrm{~nm}$. Wine quality, as well as aroma quality (determined with the nose for wines containing residual sugar) was determined by 20 experienced judges, using a nine-point scoring system (Tromp \& Conradie, 1979). The mean scores were expressed as a percentage.

\section{Laboratory Trial}

Small scale fermentations were conducted in $750 \mathrm{~m} l$ bottles utilising $500 \mathrm{~m} l$ aliquots of settled Chenin blanc and Colombar juices. Copperoxychloride was added to obtain final copper concentrations of $0,10,20,30,50$ and $70 \mathrm{mg} / l$. Two yeast strains viz: WE 500 and WE 14 (both from the VORI collection) were used to inoculate the musts at a pitching rate of $0,5 \mathrm{~g} / l$ of rehydrated dried yeast. Duplicate fermentations proceeded at $15^{\circ} \mathrm{C}$. Fermentation curves were obtained by plotting daily mass loss due to the evolution of $\mathrm{CO}_{2}$. After fermentation the copper concentration of both the wine and the yeast sediment was determined.

\section{RESULTS AND DISCUSSION}

\section{Effect of Copper on Fermentation}

Chenin blanc field trial: The fermentation curves as well as copper concentrations of the musts from the three treatments can be seen in fig. 1. It is evident that where vines were sprayed in a comprehensive program of six sprays, with the last one applied three days before harvest, the settled musts had a much higher copper content than those from grapes where the program was terminated 14 days before harvest $(43,6 \mathrm{mg} / l$ as against $13,1 \mathrm{mg} / l)$. The $13,1 \mathrm{mg} / l$ determined in the latter case is higher than the $3,91 \mathrm{mg} / \mathrm{l}$ copper found by Eschenbruch \& Kleynhans (1974) in musts after an almost identical spraying program which was terminated seven days before harvest. This can probably be attributed to the fact that the vineyard in this trial was handsprayed and more of the fungicide was thus concentrated on the grapes. Lemperle \& Lay (1984) found a copper concentration of $34 \mathrm{mg} / \mathrm{kg}$ on grapes 14 days after the last copper spray had been applied. It is further evident from Fig. 1 that a copper concentration in excess of $40 \mathrm{mg} / \mathrm{l}$ caused serious lagging of fermentation: After 70 days none of the four replicates had fermented more than $35 \%$ of their original sugar concentration. Lagging fermentation even occurred where spraying was terminated fourteen days before harvest - two of the four replicates not fermenting to dryness (data not shown) while those of the untreated control achieved this in 30 days. 


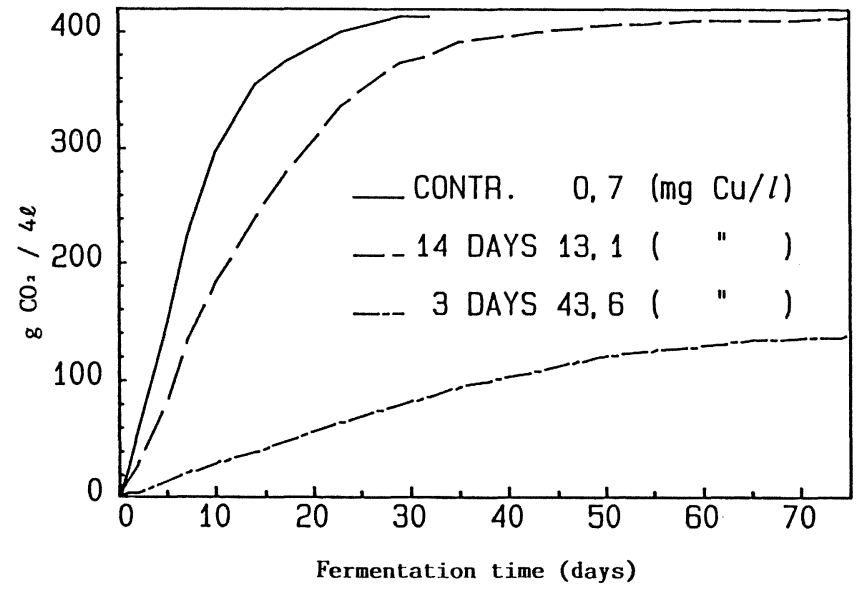

FIG. 1

Mean copper concentrations and fermentation curves of four replicates of musts of Chenin blanc grapes which were: untreated (contr.); sprayed 5 times with $\mathrm{CuOCl}$ with the last spray applied 14 days before harvest (14 days); sprayed 6 times with $\mathrm{CuOCl}$ with the last spray applied 3 days before harvest ( 3 days). (Yeast strain WE 500 at $15^{\circ} \mathrm{C}$ ).

Colombar field trial: The copper concentrations of settled musts obtained from the different spraying treatments can be seen in Fig. 2. In the case of the control, less than $1 \mathrm{mg} / \mathrm{l}$ copper was present. This trace of copper was due to an earlier spraying about six weeks before harvest. From Fig. 2 it is evident that a single treatment with copperoxychloride, whether applied 14, 7 or 3 days before harvest, did not increase the copper concentration to a large extent. Two sprays with copperoxychloride, however, led to a marked increase of approximately $6-7 \mathrm{mg} / \mathrm{l}(14+7$ and $14+3)$. Where three sprays were applied $(14+7+3)$ a copper concentration of as high as $16 \mathrm{mg} / \mathrm{l}$ was found.

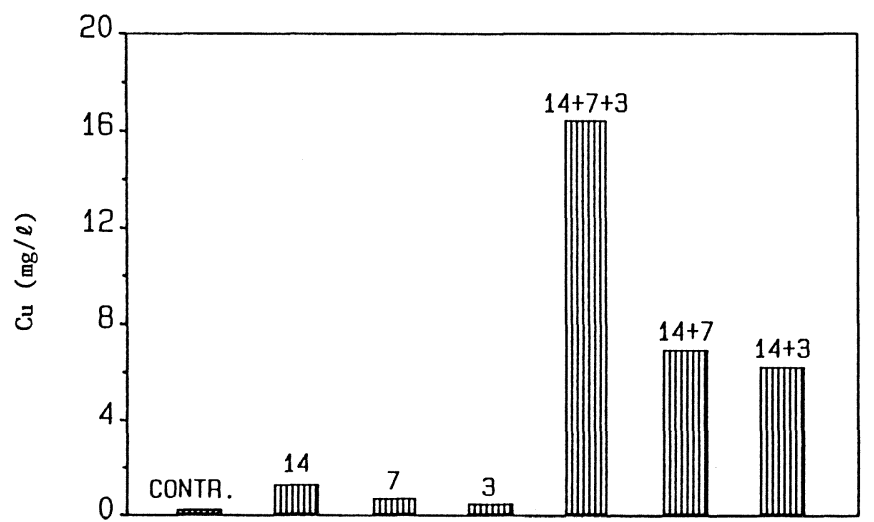

Treatments

FIG. 2

Mean copper concentrations of musts from Colombar grapes sprayed with $\mathrm{CuOCl}$ (Different combinations of 3, 7 and 14 days before harvest against an untreated control).

The mean fermentation curve for the musts from the untreated control grapes as well as that from grapes sprayed at $14+7+3$ days before harvest can be seen in Fig. 3. It is clear that the latter fermentation and even that of the control treatment experienced lagging and after 80 days residual sugar was in fact still found in the wines. This can probably be attributed to the musts being very clear and virtually devoid of solids (Tromp, 1984; Houtman \& Du Plessis, 1986). The $14+7+3$ treatment nevertheless caused an additional lagging of fermentation while the fermentation curves of the musts of the other treatments (not shown) were identical to that of the control.

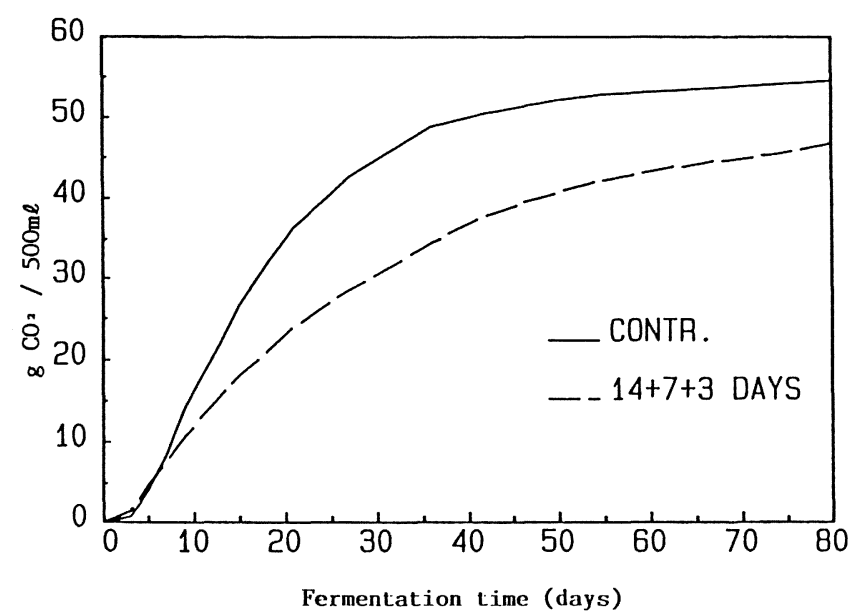

FIG. 3

Fermentation curves of Colombar musts of which the grapes received three sprays of $\mathrm{CuOCl}$ on 14,7 and 3 days before harvest against an untreated control. (Yeast strain WE 500 at $15^{\circ} \mathrm{C}$ ).

Laboratory trial: The effect of copper on the rate of fermentation was found to be independent of cultivar and yeast strain. A copper concentration as low as $10 \mathrm{mg} / \mathrm{l}$ seriously retarded the rate of fermentation. In Fig. 4 the fermentation curves for WE 14 in Chenin blanc must are given as an example.

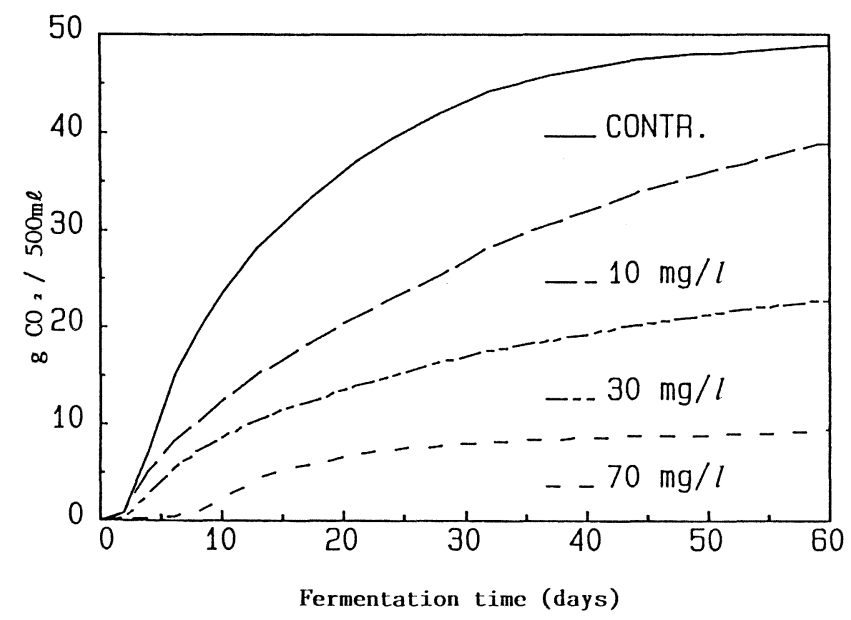

FIG. 4

Fermentation curves of Chenin blanc musts to which different concentrations of $\mathrm{Cu}(\mathrm{CuOCl})$ were added against an untreated control (Yeast strain WE 14 at $15^{\circ} \mathrm{C}$ ).

When considering the results of the field and laboratory trials it is clear that the spraying of a vineyard with copperoxychloride up to 14 days before harvest or closer, yielded copper concentrations in the settled musts that ranged between $2 \mathrm{mg} / \mathrm{l}$ and $43,6 \mathrm{mg} / \mathrm{l}$. Fermentation was seriously retarded in some of these cases. The results of the laboratory trial support these findings: Copper concentrations of $10 \mathrm{mg} / \mathrm{l}$ affected the rate of 
fermentation negatively and one would expect that even lower concentrations would have the same effect. Tromp (1980) in fact pointed out that $8 \mathrm{mg} / \mathrm{l}$ of copper in settled Chenin blanc musts increased the fermentation time from 33 to 37 days.

\section{Presence of Copper in Wine and Yeast Sediment after Fermentation}

The mean copper concentrations for wine and yeast sediment can be seen in Fig. 5 where the mean data for WE 14 and WE 500 in Chenin blanc musts are given. These results agree with those found in the Colombar must. In the case of the control where no copperoxychloride was added prior to fermentation, no copper could be found in the wine whilst only traces were found in the sediment. At an initial copper concentration of $10 \mathrm{mg} / \mathrm{l}$ virtually all the copper was found in the yeast sediment whilst only about $0,7 \mathrm{mg} / \mathrm{l}$ resided in the wine. This is in accordance with the findings of Würdig (1969) who found that $8 \mathrm{mg} / \mathrm{l}$ of copper was removed by the yeast from must. At $20 \mathrm{mg} / l$, about $15 \mathrm{mg} / l$ was found in the yeast and $5 \mathrm{mg} / \mathrm{l}$ in the wine. When studying Fig. 5 it is evident that any further increases in initial copper concentrations will not be taken up or sedimented by the yeast and will remain in the wine. At these higher concentrations there was actually a somewhat contradictory tendency for the copper to be lower in the yeast sediment - most probably because of the presence of fewer yeast cells under these limiting conditions. It is, however, of more importance to note that residual copper was found in wines where the initial copper concentration of the must was only $10 \mathrm{mg} / \mathrm{l}$. This is somewhat contradictory to the conclusion drawn by Thoukis \& Amerine (1956). They found residual copper concentrations of $1-2,5 \mathrm{mg} / \mathrm{l}$ in wine when the copper content of the must was only $5-5,5 \mathrm{mg} / l$. This could mean that different yeast strains are responsible for leaving different copper residues in wine. These residues may be responsible for problems with oxidation or the forming of turbidity during maturation of such wines.

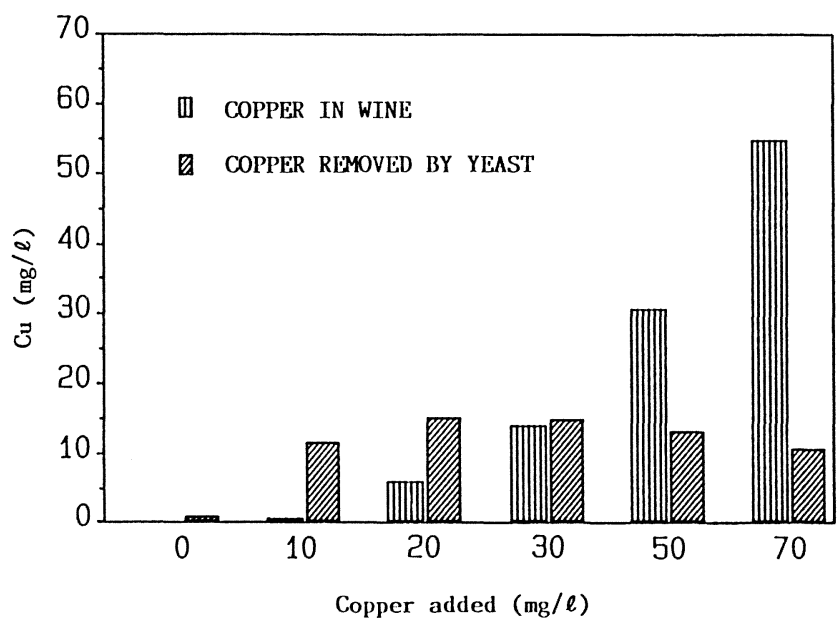

FIG. 5

Mean copper concentrations in wines and copper removed by yeast after fermentation of musts to which $\mathrm{CuOCl}$ was added prior to fermentation to yield final copper concentrations of $0,10,20,30,50$ and $70 \mathrm{mg} / \mathrm{l}$. (Mean data for Chenin blanc and Colombar as well as yeast strains WE 14 and WE 500).

\section{The Effect of Copper in Must on Subsequent Wine Quality}

The negative effect of copper on wine quality was evident from the very first stages of the winemaking procedure through to the final wine. In the case of Chenin blanc the settled musts showed a marked difference in colour between the three treatments (Plate 1). Whereas the untreated control yielded a must with a "normal" strawy-yellow colour, the must from grapes which were sprayed up to 14 days before harvest was brownish and that from grapes sprayed up to 3 days before harvest was green. The colour of the musts after a few days of fermentation can be seen in Plate 2 . It is evident that although the colour of the control and that of the treatment where the grapes were sprayed up to 3 days before harvest had not changed, that of the treatment where copperoxychloride was applied up to 14 days before harvest had turned dark brown. All four replicates of the " 3 days before harvest" treatment as well as 2 of the " 14 days before harvest" treatment did not ferment to dryness and wine quality was thus seriously impaired.

In Fig. 6 the quality of the two " 14 days before harvest" replicates that did ferment to dryness can be seen against that of the four controls. Control wines 2 and 4 were highly significantly higher in quality than both the "14 days before harvest" wines while the third control wine was also significantly better than one of the "14 days before harvest" wines. Although all control wines were therefore not significantly higher in quality there was a definite tendency towards lower quality when wines were made from grapes that were sprayed with copper up to 14 days before harvest.

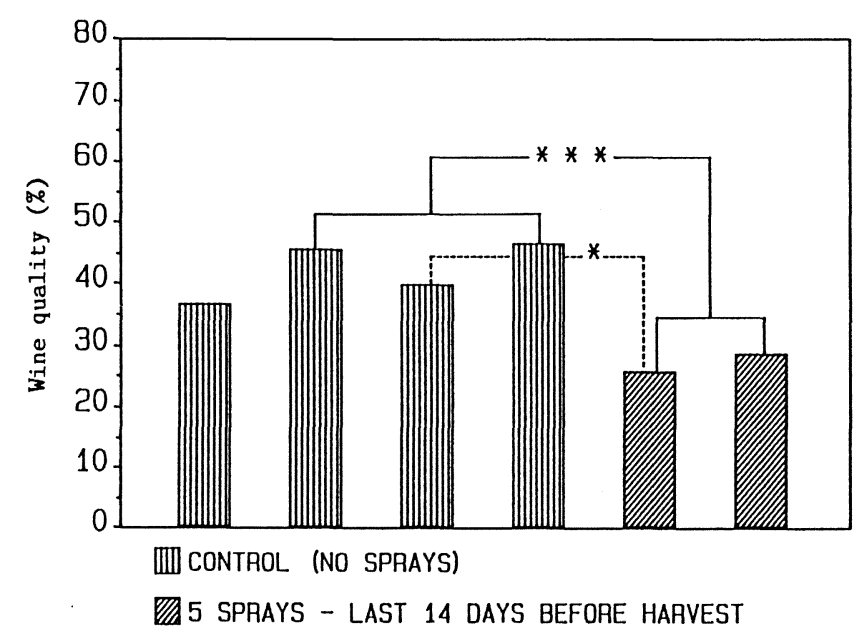

FIG. 6

Quality of Chenin blanc wines from grapes which received 5 sprays of $\mathrm{CuOCl}$, the last of which was applied 14 days before harvest (2 reps.) against that of an untreated control (4 reps)

***Very highly significant and *significant according to the Friedman test for non-parametric data.

The Colombar trial yielded the following results with respect to wine quality: During fermentation the colour of the four replicate musts that were obtained from grapes sprayed $14+7+3$ days before harvest, were noticeably browner than those of the control (Plate 3$)$. This supports the findings of Würdig (1969) who found that copper concentrations in excess of $15 \mathrm{mg} / \mathrm{l}$ causes 
serious browning of the must. This darker colour was later also encountered in the wine (Fig. 7). This was to be expected as a copper concentration of as low as $0,5 \mathrm{mg} / \mathrm{l}$ has been shown to cause oxidative browning in white wines (Diaz, 1979). Although not significantly so, a tendency was also observed for colour density at $420 \mathrm{~nm}$ to be higher in the case of other treatments where copper spraying was applied. A very important observation illustrated in Fig. 7 is that the control wine was highly significantly higher in aroma quality than any of the other wines where copper spraying was utilised close to harvest, even in the case where only one spray was applied 14 days before harvest.

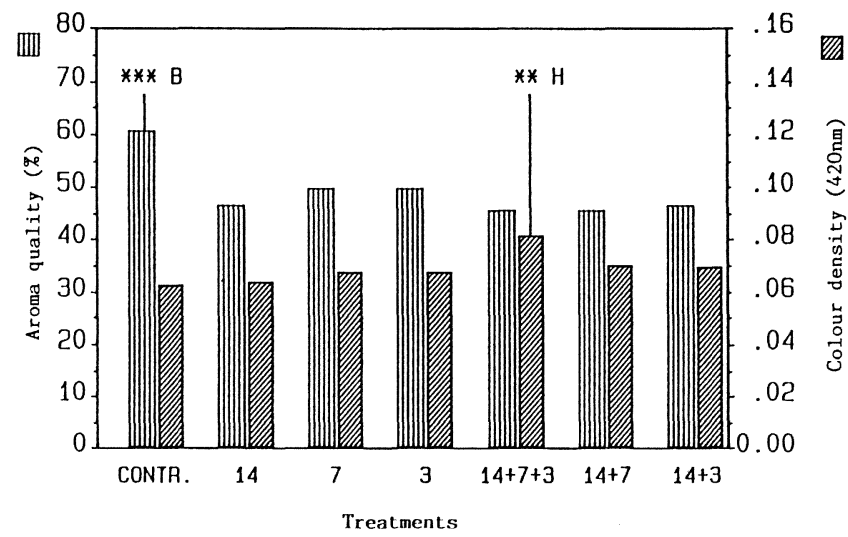

FIG. 7

Aroma quality and colour density of Colombar wines from grapes which received combinations of $\mathrm{CuOCl}$ sprays at 14,7 and 3 days before harvest against that of an untreated control.

${ }^{* * *} \mathrm{~B}$ signifies very highly significantly better and ${ }^{* *} \mathrm{H}$ highly significantly higher in colour according to the Friedman test for non-parametric data.

For both die Chenin blanc and Colombar trials it was found that spraying with copper up to 14 days before harvest affected wine quality negatively. Eschenbruch (1971) warned that spraying with copper-containing fungicides closer than 8 weeks before harvest could cause problems with $\mathrm{H}_{2} \mathrm{~S}$ formation. The wines in this study did not have poorer quality because of sulphury tones but rather because of oxidation. The lack of $\mathrm{H}_{2} \mathrm{~S}$ character could be ascribed to a high enough free amino nitrogen content in the musts (Vos \& Gray, 1979). Most South African winemakers add nitrogen to their musts and therefore should not experience problems with wine quality, as far as $\mathrm{H}_{2} \mathrm{~S}$ formation is concerned, where copper is applied closer than 8 weeks before harvest.

\section{CONCLUSIONS}

The spraying of vineyards with copperoxychloride up to 14 days or closer to harvest causes a large incidence of lagging or stuck fermentations. Darker coloured wines are obtained and such wines have been found to be of inferior quality. Furthermore copper remaining in such wines may cause problems, such as oxidation or clouding of the wine during maturation, which will shorten shelf life. It is evident that the longer the period between the last application of copper and the harvest date, the fewer problems will be experienced with lagging fermentation and wine quality.

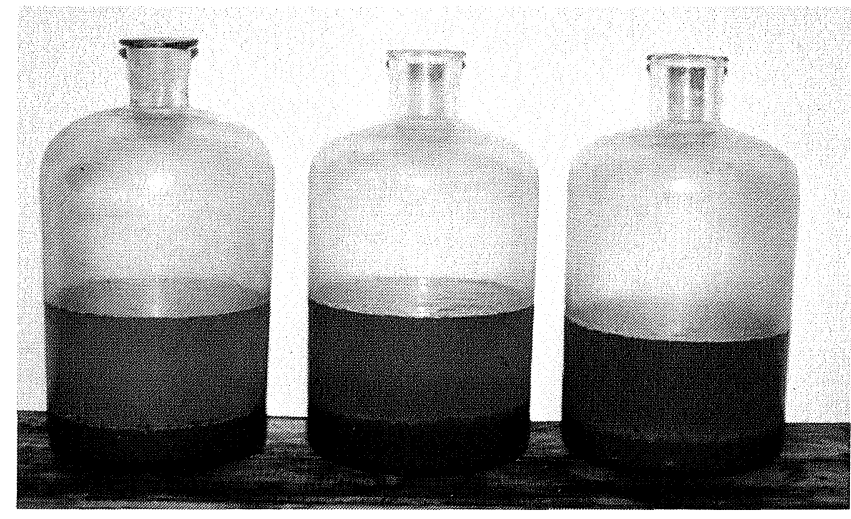

PLATE 1

Musts from Chenin blanc grapes that were (from left to right): untreated; sprayed five times with $\mathrm{CuOCl}$ with the last spray applied 14 days before harvest; sprayed six times with the last spray applied 3 days before harvest.

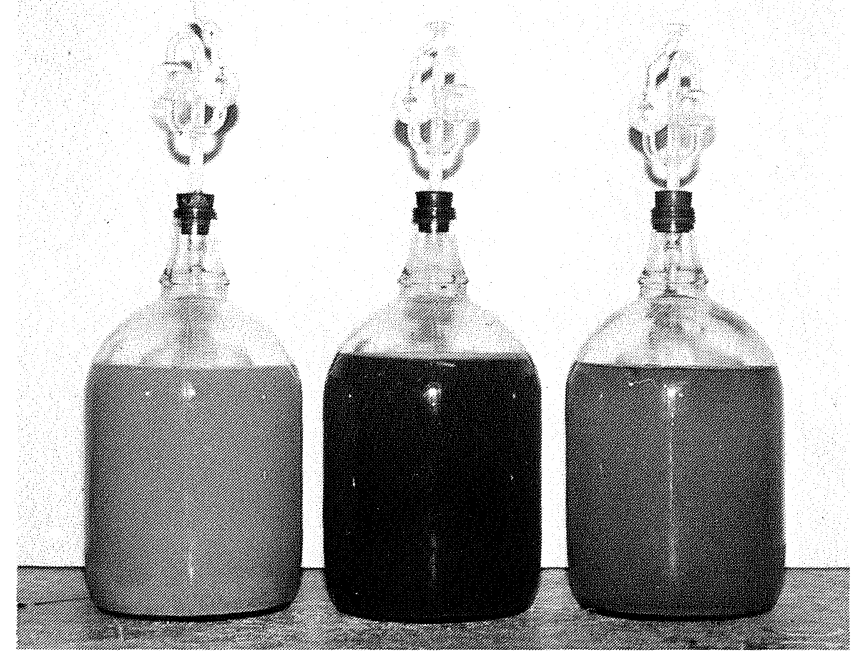

PLATE 2

Chenin blanc musts after ten days of fermentation from grapes that were (from left to right): untreated; sprayed five times with $\mathrm{CuOCl}$ with the last spray applied 14 days before harvest; sprayed six times with the last spray applied 3 days before harvest.

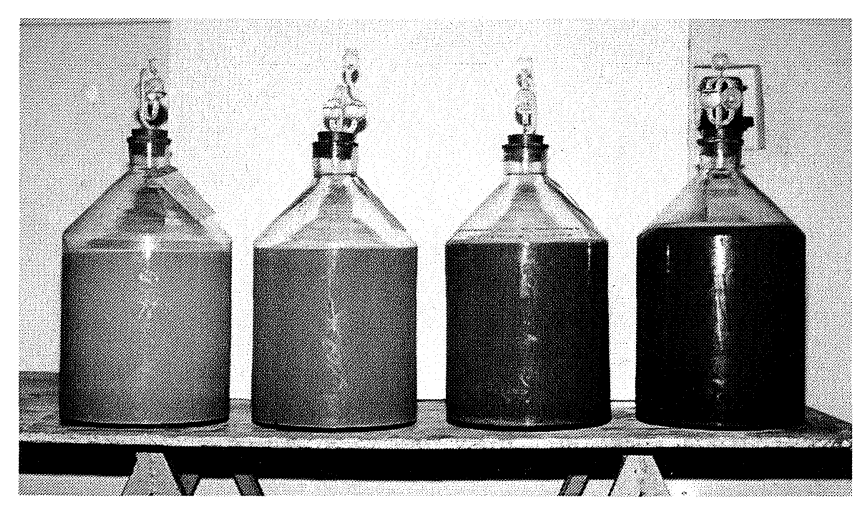

PLATE 3

Colombar musts after seven days of fermentation from grapes that were: untreated (the two on the left); sprayed at $14+7+3$ days before harvest (the two on the right). 


\section{LITERATURE CITED}

CONNER, A.J., 1983. The comparative toxicity of vineyard pesticides to wine yeast. Am. J. Enol. Vitic. 34, 278-279.

DIAZ, M.R., 1979. Effects of copper content on the dusky color of white wine. Sem. vitivinic. 34, 775-783 (Abstr. Chem Abs. 90 (13), 202183f, 1979)

DIETER, VON A., 1979. Untersuchungen über den Einfluss von Fungiciden auf Gärung und Weingeschmack. Die Weinwirtschaft 49, 1507-1508.

ESCHENBRUCH, R., 1971. The influence of fungicides on the formation of hydrogen sulphide $\left(\mathrm{H}_{2} \mathrm{~S}\right)$ during the fermentation of grape juice. Wynboer 482, 22-23.

ESCHENBRUCH, R. \& KLEYNHANS, P.H., 1974. The influence of copper-containing fungicides on the copper content of grape juice and on hydrogen sulphide formation. Vitis 12, 320-324.

HAESELER, C.W. \& PETERSEN, D.H., 1974. Effect of cupric hydroxide vineyard sprays on Concord grape yields and juice quality. Plant Dis. Reptr 58, 486-489.

HOUTMAN, A.C. \& DU PLESSIS, C.S., 1986. Nutritional deficiencies of clarified white grape juices and their corrections in relation to fermentation. S. Afr. J. Enol. Vitic. 7, 39-46.

LEMPERLE, VON E. \& LAY, H., 1984. Kupfergehalte auf Weintrauben in Traubenmost und in Wein. Die Weinwirtschaft Technik 8, 221-224.

SAPIS-DOMERQ, S., 1980. Etude de l'influence des produits de traitement de la vigne sur la microflore des raisins et des vins. Connaissance Vigne Vin 14, 155-181.

SAPIS-DOMERQ, S., BERTRAND, A., JOYEUX, A., LUCMARET, V. \& SARRE, C., 1978. Etude de l'influence des produits de traitement de la vigne sur la microflore des raisins et des vins. Comparaison avec les resultats de 1976 et 1975. Connaissance Vigne Vin 12, 245-275.

THOUKIS, G. \& AMERINE, M.A., 1956. The fate of copper and iron during fermentation of grape mutsts. Am. J. Enol. Vitic. 7, $45-52$.

TROMP, A., 1980. Die invloed van verskillende faktore op gisting en wyngehalte met spesiale verwysing na slepende gisting. In: Short course in Oenology. VORI Private Bag X5026, 7600 Stellenbosch, Republic of South Africa, pp. 35-42.

TROMP, A., 1984. The effect of yeast strain, grape solids, nitrogen and temperature on fermentation rate and wine quality. $S$. Afr. J. Enol. Vitic. 5, 1-6.

TROMP, A. \& CONRADIE, W.J., 1979. An effective system for the sensory evaluation of experimental wines. Am. J. Enol. Vitic. 30, 278-283.

VOS, P.J.A. \& GRAY, R.S., 1979. The origin and control of hydrogen sulphide during fermentation of grape must. Am. J. Enol. Vitic. 30, 187-197.

WÜRDIG, G., 1969. Über den Kupfergehalt von Wein. Rebe und Wein 22, 130-134. 